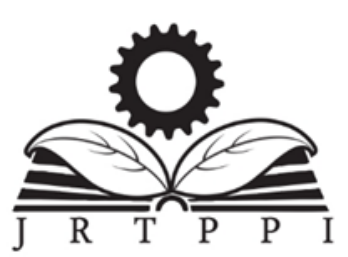

Vol. 10 No. 2 (2019) 7-15

Jurnal Riset

Teknologi Pencegahan Pencemaran Industri

Kementerian

Perindustrian

REPUBLIK INDONESIA

Journal homepage : jrtppi.id

\title{
Nitrogen Removal in the Anammox Biofilm Reactor using Palm Fiber as Carrier in Tropical Temperature Operation
}

\author{
Zulkarnaini $^{1}$, Ansiha Nur ${ }^{1}$, Wina Ermaliza ${ }^{1}$ \\ ${ }^{1}$ Departement of Environmental Engineering, Universitas Andalas
}

\begin{tabular}{|c|c|}
\hline A R T IC L E I N F O & A B S T R A C T \\
\hline $\begin{array}{l}\text { Article history: } \\
\text { Received 09 September } 2019 \\
\text { Received in revised form } 23 \text { November } \\
2019 \\
\text { Accepted } 29 \text { November } 2019 \\
\text { Available online } 16 \text { December } 2019\end{array}$ & 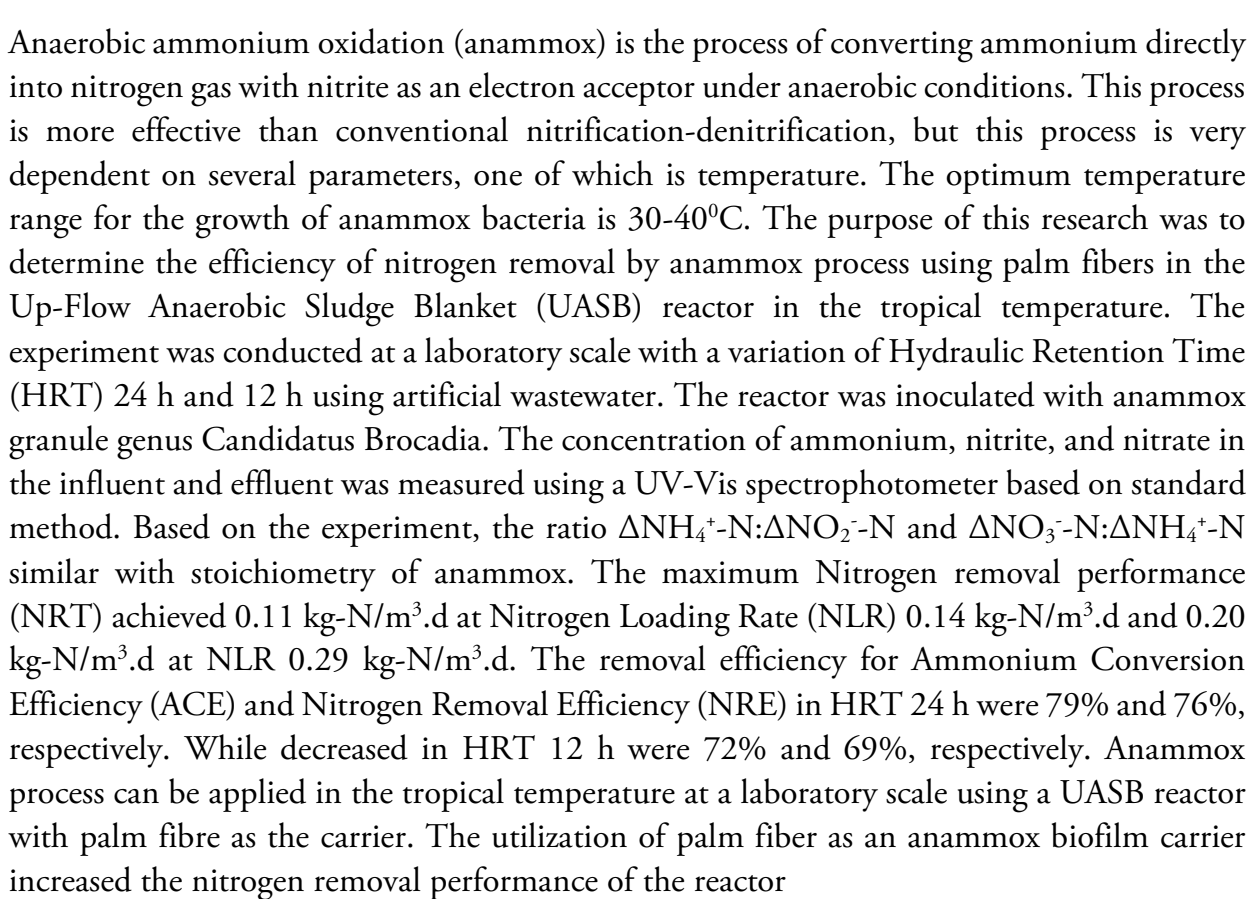 \\
\hline
\end{tabular}

\section{INTRODUCTION}

The presence of high nitrogen concentration in effluent wastewater can have a negative impact on receiving water bodies such as reduced dissolved oxygen, promoted eutrophication, and increase the level of toxicity of a water body. Therefore, it needs to be treated before being discharged into water bodies to meet the regulation of quality standards. One of the preferred treatment is a biological process by utilizing microorganisms to degrade organic compounds and to reduce the nitrogen content in wastewater (Gerardi 2002).

Conventional process for removing nitrogen from wastewater was nitrification-denitrification. These process required high costs for aeration and external organic carbon sources for the denitrification process (Szatkowska and Paulsrud 2014). Nowadays, application nitrificationdenitrification replaced with anaerobic ammonium

\footnotetext{
${ }^{*}$ Correspondence author.

E-mail : zulkarnaini@gmail.com
} 
oxidation (anammox) process. Anammox is a biological process in which nitrite is used as an electron acceptor in the conversion of ammonium to nitrogen gas (Mulder et al. 1995). Anammox process compared to other conventional nitrogen removal processes is more effective because anammox can reduce aeration by $64 \%$, organic carbon $100 \%$, and sludge production $80-90 \%$ (van Loosdrecht 2008).

Research related to the anammox process has been carried out with various operational variations such as the type of reactor used (Fluidized Bed Reactor, Membrane Bioreactor (MBR), Sequencing Batch Reactor (SBR), UpFlow Anaerobic Sludge Blanket (UASB), Anaerobic Baffled Biofilm Reactor (ABBR)), Gas Lift Reactor and other modifications; mode of operation (batch and continue), bacterial species (generally Candidatus Brocadia and Candidatus Kuenenia), variations of substrate, temperature, $\mathrm{pH}$, salinity, using supporting media (non-woven, membrane, sponge, bamboo charcoal, Polyvinyl Alcohol sodium Alginate Gel Beads, Acrylic Resin Material, Polyethylene Sponge Strips, Spherical Plastic, and string wound filter) (Zulkarnaini et al. 2018). At present more than 114 anammox reactor operated in the world, most of them in Europe, China, and North of America (Ali and Okabe 2015) as sub-tropical countries.

Indonesia, as a tropical country, has a potential opportunity for application of anammox process because of the temperature is suitable for the growth of anammox bacteria (Marc Strous, Kuenen, and Jetten 1999b). The purpose of this research was the analyze the nitrogen removal performance of anammox biofilm reactor in the tropical temperature using palm fiber as a carrier in a UASB reactor. Palm fiber was used as supporting media for anammox biofilm. These fibers have the characteristics: not easily decomposed, durable, and waterproof (Widyawati 2011). As a carrier, palm fibers also reduced the biomass wash-out from the reactor. The use of palm fiber media in the reactor as intended to influence reactor performance. Minimizing the amount of anammox bacteria wash-out and increasing the retention rate is a strategic key in starting up an anammox reactor and stabilizing operating conditions (C. Chen et al. 2012). Biofilm reactors are the best way to process anammox in reducing the biomass wash-out from the reactor (M. Strous, Heijnen, Kuenen, and Jetten 1998).

\section{METHODS}

A $300 \mathrm{~mL}$ UASB reactor was operated for anammox biofilm reactor. For the start-up, granular anammox bacteria genus Candidus Brocadia from Kanazawa University, Japan, inoculated into the reactor, Figure 2(a). Palm fiber as the carrier was filled into the reactor with $50 \%$ in volume, Figure 2(b). The substrate with the composition described in Table 1 was pumped into the reactor from the bottom, using a peristaltic pump. The substrate tank was connected to a gas bag containing nitrogen gas to maintain anaerobic conditions and regulate the balance of atmospheric pressure in the tank. The effluent will flow to the top of the reactor. This experiment was carried out with variations in HRT $24 \mathrm{~h}$ and $12 \mathrm{~h}$. The research installation scheme can be seen in Figure 1.

Table 1. Composition of artificial wastewater (Graaf et al. 1996)

\begin{tabular}{ll}
\hline Substrates & Concentration $(\mathrm{mg} / \mathrm{L})$ \\
\hline$\left(\mathrm{NH}_{4}\right)_{2} \mathrm{SO}_{4}$ & $330(70 \mathrm{mg}-\mathrm{N} / \mathrm{L})$ \\
$\mathrm{NaNO}_{2}$ & $345(70 \mathrm{mg}-\mathrm{N} / \mathrm{L})$ \\
$\mathrm{MgSO}_{4} \cdot 7 \mathrm{H}_{2} \mathrm{O}$ & 300 \\
$\mathrm{CaCl}_{2} \cdot 7 \mathrm{H}_{2} \mathrm{O}$ & 180 \\
$\mathrm{KH}_{2} \mathrm{PO}_{4}$ & 27.2 \\
$\mathrm{KHCO}_{3}$ & 500 \\
Trace element I and II & $1 \mathrm{~mL} / \mathrm{L}$ \\
\hline
\end{tabular}




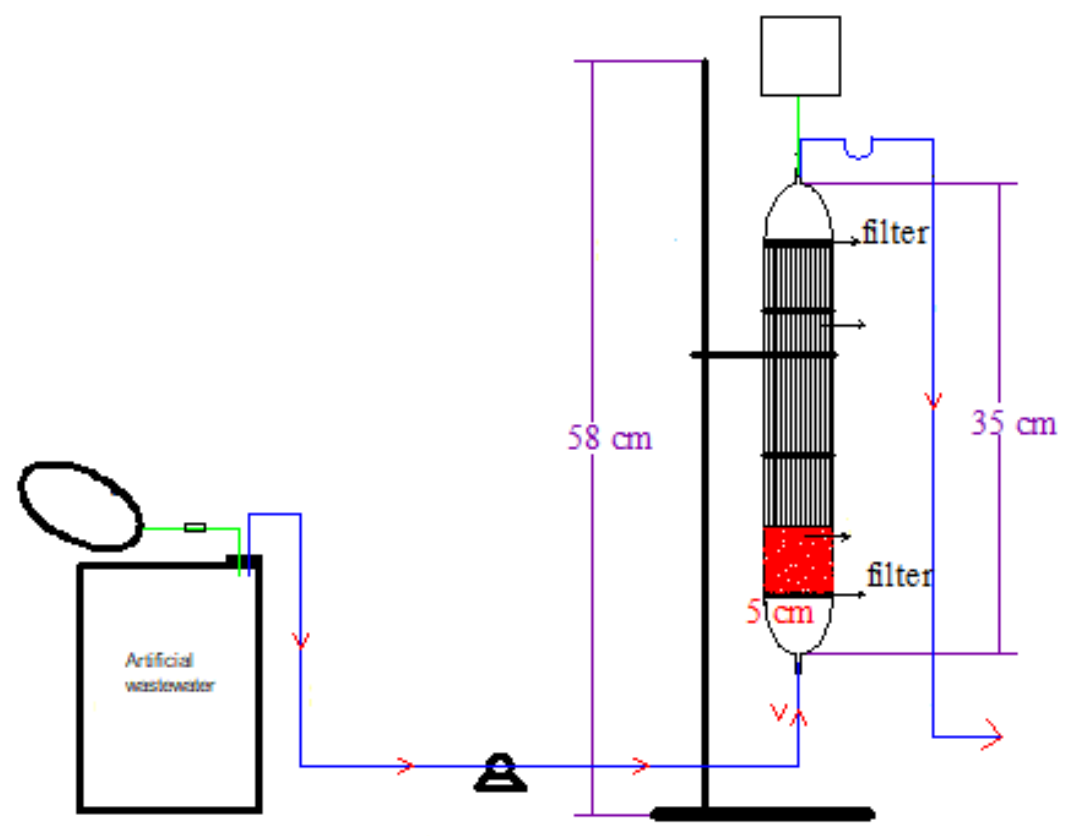

Figure 1. Reactor installation scheme.

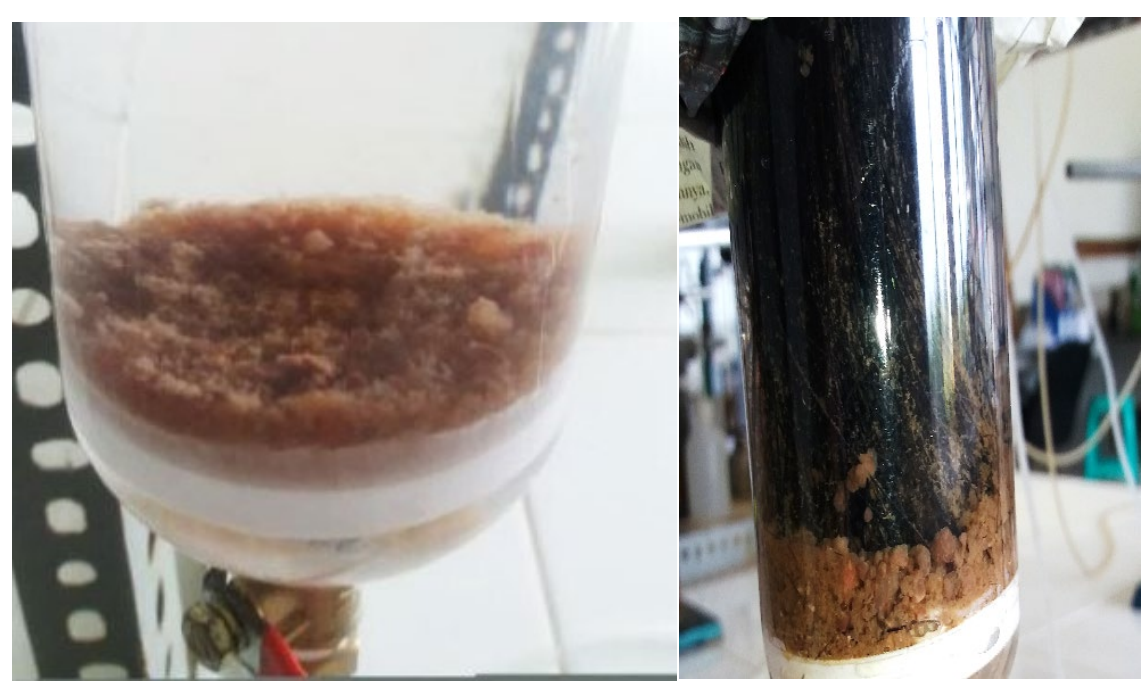

Figure 2. Anammox granular as seeding sludge (a) and palm fiber as the carrier (b) for start-up reactor.

Samples collected twice a week and measured directly using UV-Vis Spectrophotometer based on standard method (American Public Health Association, American Water Works Association 1999). Performance of anammox biofilm reactor in the tropical temperature was expressed with nitrogen removal rate (NRR, $\left.\mathrm{kg}-\mathrm{N} / \mathrm{m}^{3} . \mathrm{d}\right)$, ammonium conversion efficiency (ACE, \%), and nitrogen removal efficiency (NRE, \%), calculated based on the following equations : 


$$
\begin{aligned}
& \mathrm{NRR}=\frac{\left[\mathrm{NH}_{4}^{+}-\mathrm{N}\right]_{\text {in }}+\left[\mathrm{NO}_{2}^{-}-\mathrm{N}\right]_{\mathrm{in}}-\left[\mathrm{NH}_{4}^{+}-\mathrm{N}\right]_{\mathrm{eff}}-\left[\mathrm{NO}_{2}^{-}-\mathrm{N}\right]_{\text {eff }}-\left[\mathrm{NO}_{3}^{-}-\mathrm{N}\right]_{\mathrm{eff}}}{\mathrm{HRT}} \\
& \mathrm{ACE}=\frac{\left[\mathrm{NH}_{4}^{+}-\mathrm{N}\right]_{\mathrm{in}}-\left[\mathrm{NH}_{4}^{+}-\mathrm{N}\right]_{\text {eff }}}{\left[\mathrm{NH}_{4}^{+}-\mathrm{N}\right]_{\text {in }}} \times 100 \% \\
& \mathrm{NRE}=\frac{\left.\left[\mathrm{NH}_{4}^{+}-\mathrm{N}\right]_{\text {in }}+\left[\mathrm{NO}_{2}^{-}-\mathrm{N}\right]_{\text {in }}^{-}\left[\mathrm{NH}_{4}^{+}-\mathrm{N}\right]_{\text {eff- }}-\left[\mathrm{NO}_{2}^{-}-\mathrm{N}\right]_{\text {eff }}-\left[\mathrm{NO}_{3}^{-}-\mathrm{N}\right]\right)_{\text {eff }}}{\left[\mathrm{NH}_{4}^{+}-\mathrm{N}\right]_{\text {in }}+\left[\mathrm{NO}_{2}^{-}-\mathrm{N}\right]_{\text {in }}} \times 100 \%
\end{aligned}
$$

The inhibition parameters, the concentration of free ammonia $\left(\mathrm{C}_{\mathrm{FA}}, \mathrm{mg} / \mathrm{L}\right)$, and free nitrous acid $\left(\mathrm{C}_{\mathrm{FNA}}\right.$, $\mathrm{mg} / \mathrm{L}$ ) were calculated based on the following equations:

$$
\begin{aligned}
& \mathrm{C}_{\mathrm{FA}}=\frac{17}{14} \frac{\mathrm{C}_{\mathrm{t}, \mathrm{NH}} \times 10^{\mathrm{pH}}}{\mathrm{e}^{6344 /(273+\mathrm{T})}+10^{\mathrm{pH}}} \\
& \mathrm{C}_{\mathrm{FNA}}=\frac{47}{14} \frac{\mathrm{C}_{\mathrm{t}, \mathrm{NO}_{2}}}{\mathrm{e}^{-2300 /(273+\mathrm{T})} \times 10^{\mathrm{pH}}+1}
\end{aligned}
$$

\section{RESULT AND DISCUSSION \\ Stoichiometry anammox}

Anammox process can be observed with the conversion of ammonium, nitrite, and produced nitrate in the reactor, Figure 3 - 4. Identifying the anammox processes in the reactor can use the stoichiometric reaction relationship proposed by (M. Strous, Heijnen, Kuenen, Jetten, et al. 1998) as follows:

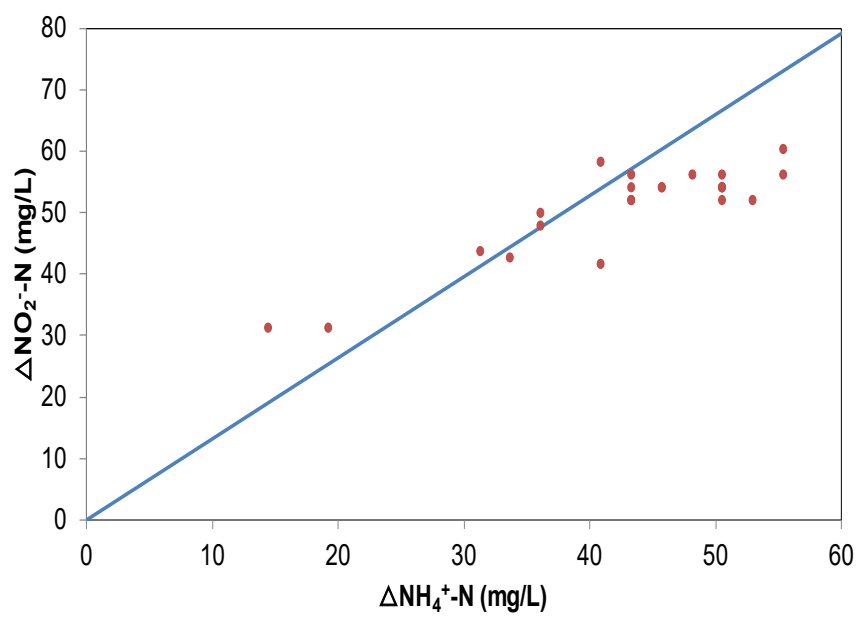

Figure 3. The experimental ratio of $\Delta \mathrm{NO}_{2}{ }^{-}-\mathrm{N} / \Delta \mathrm{NH}_{4}^{+}-\mathrm{N}$, the blue line is the ratio based on stoichiometry anammox process of 1.32

$$
\begin{aligned}
& \mathrm{NH}_{4}^{+}+1.32 \mathrm{NO}_{2}^{-}+0.066 \mathrm{HCO}_{3}^{-}+0.13 \mathrm{H}+\rightarrow 1.02 \mathrm{~N}_{2}+ \\
& 0.26 \mathrm{NO}_{3}^{-}+0.066 \mathrm{CH}_{2} \mathrm{O} 0,5 \mathrm{~N}_{0,15}+2.03 \mathrm{H}_{2} \mathrm{O}
\end{aligned}
$$

The results showed an average ratio of $\Delta \mathrm{NO}_{2}$ $\mathrm{N} / \Delta \mathrm{NH}_{4}{ }^{+}-\mathrm{N}$ was 1.24 and for the ratio of $\Delta \mathrm{NO}_{3}{ }^{-}$ $\mathrm{N} / \Delta \mathrm{NH}_{4}{ }^{+}-\mathrm{N}$ was 0.24 . The rates were lower than stoichiometric that indicated the possibility of a denitrification process takes place in the reactor. Where nitrate is reduced by denitrifier bacteria to $\mathrm{N}_{2}$ gas using organic compounds derived from biomass decay (dead anammox bacteria) (Kindaichi et al. 2007), this difference in stoichiometric ratio can be influenced by the physiological of anammox bacteria, experimental conditions (nitrogen loading, temperature, and $\mathrm{pH}$ ) and microbial populations (Puyol et al. 2013).

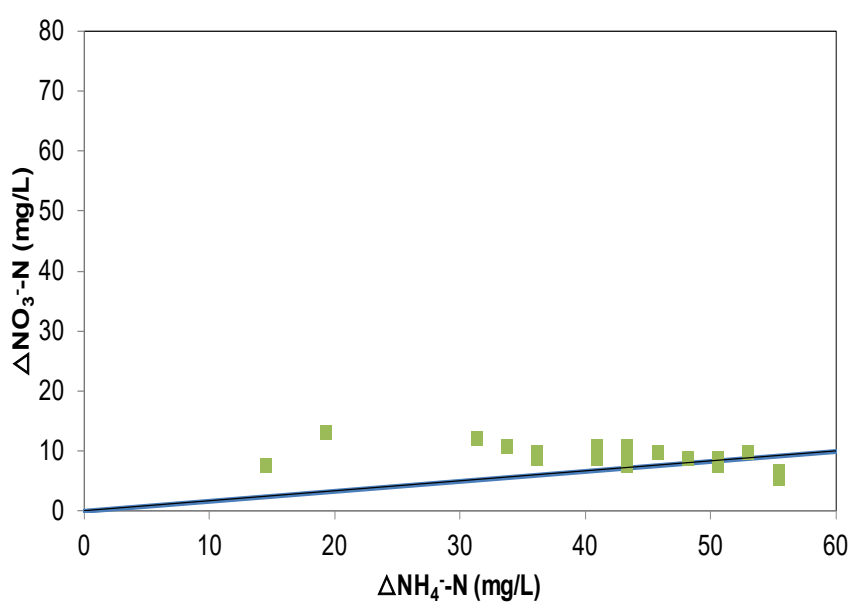

Figure 4. Ratio $\Delta \mathrm{NO}_{3}{ }^{-} \mathrm{N} / \Delta \mathrm{NH}_{4}{ }^{+}-\mathrm{N}$, the dark blue line is the ratio based on stoichiometry anammox process of 26 
Profile of nitrogen in the operation

\section{Ammonium}

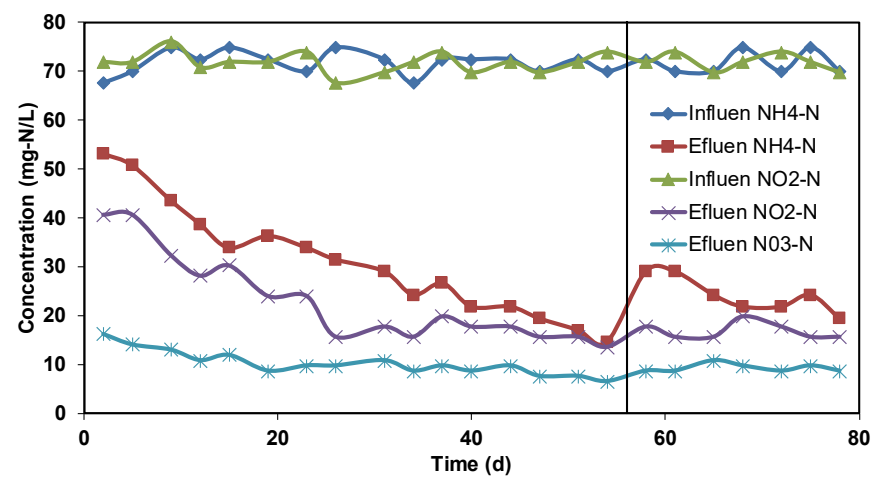

Figure 5. Profile of nitrogen in the operation

Profile of nitrogen concentrations in the influent and effluent during the experiment was illustrated in Figure 5. In the graph, it can be seen that in the period I the effluent concentrations of ammonium have gradually decreased from $53.25 \mathrm{mg}-\mathrm{N} / \mathrm{L}$ to $14.70 \mathrm{mg}-\mathrm{N} / \mathrm{L}$. While in period II, there was an increased ammonium concentration from $14.70 \mathrm{mg}-\mathrm{N} / \mathrm{L}$ to $29.16 \mathrm{mg}-\mathrm{N} / \mathrm{L}$ due to changes in HRT from $24 \mathrm{~h}$ to $12 \mathrm{~h}$. Then, decreased gradually and achieved $19.52 \mathrm{mg}-\mathrm{N} / \mathrm{L}$ at the end of the operating reactor. Ammonium is a substrate for anammox bacteria. Decreased of ammonium concentration in experiments in both periods I and II indicated the occurrence of anammox process in the reactor.

\section{Nitrite}

Nitrite concentration has an essential role in the anammox process. Besides as a substrate for anammox bacteria, higher or lower nitrite concentrations can have a negative effect of inhibiting the growth of anammox bacteria, reversible or irreversible inhibition (Marc Strous, Kuenen, \& Jetten, 1999a). The nitrite concentration in the artificial wastewater is $70 \mathrm{mg}-\mathrm{N} / \mathrm{L}$, which was below the threshold of inhibition of the anammox process by nitrite concentration of $0.1 \mathrm{~g}-\mathrm{N} / \mathrm{L}$ (Marc Strous, Kuenen, and Jetten 1999a). The concentration of nitrite in the influent and effluent illustrated in Figure 5, it can be seen that effluent concentrations of nitrite in the period I decreased gradually from $40.75 \mathrm{mg}-\mathrm{N} / \mathrm{L}$ to $13.72 \mathrm{mg}-\mathrm{N} / \mathrm{L}$. The concentration of nitrite effluent in period II increased at the beginning of period II due to decreased HRT from $24 \mathrm{~h}$ to
$12 \mathrm{~h}$, from $13.72 \mathrm{mg}-\mathrm{N} / \mathrm{L}$ to $17.88 \mathrm{mg}-\mathrm{N} / \mathrm{L}$ and then decreased to $15.80 \mathrm{mg}-\mathrm{N} / \mathrm{L}$. The remaining nitrite in the effluent can be interpreted that the consumption of nitrite was lower than the stoichiometry. Successful initiation of the Anammox process is indicated by the removal of stable ammonium and nitrite (W. Chen et al. 2017).

\section{Nitrate}

A small amount of nitrate produced by anammox process in anaerobic conditions. Produced nitrate was illustrated in Figure 5. On the graph, it can be seen that the produced nitrate in the first period tended to decrease from 16.38 to $6.62 \mathrm{mg}-\mathrm{N} / \mathrm{L}$. In period II, nitrate concentration was $8.75 \mathrm{mg}-\mathrm{N} / \mathrm{L}$. The presence of nitrate concentrations in the effluent indicates the operation of the anammox process.

\section{Performance of anammox biofilm reactor}

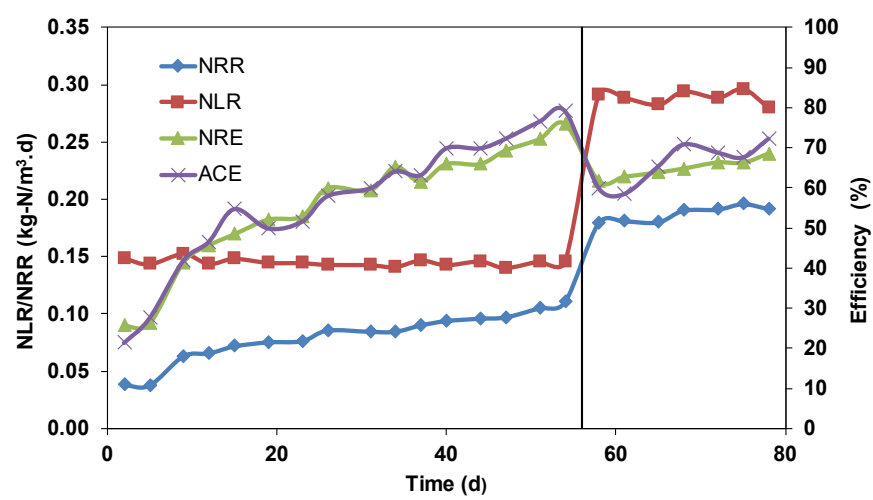

Figure 6. Performance of the anammox biofilm reactor.

\section{Temperature, $\mathrm{pH}$, free ammonia (FA) and free nitrous acid (FNA)}

The reactor was operated at ambient temperatures with the range $25-28^{\circ} \mathrm{C}$. Anammox reactors are generally performed in the high temperature $\left(\geq 30^{\circ} \mathrm{C}\right)$ and treat high ammonia containing wastewater. The optimal temperature range for the growth of anammox bacteria is between 20 $43^{\circ} \mathrm{C}$. The enzyme metabolic activity of anammox bacteria is reduced because of the temperature is lower than the optimal value of $37^{\circ} \mathrm{C}$ (Marc Strous, Kuenen, and Jetten 1999a). A lower temperature operation in the reactor caused a decrease in NRR and the efficiency of ammonium and nitrite removal in the reactor (Ma et al. 2013). In this study, the $\mathrm{pH}$ of effluent ranged from 7.3 to 7.8 were still in the 
range for the growth of anammox bacteria indicated that the experiments were carried out under optimum conditions. The results of this $\mathrm{pH}$ affect the concentration value of FA and FNA. Where if the $\mathrm{pH}$ is low, it will reduce FA but increased FNA concentration (Jin et al. 2012).

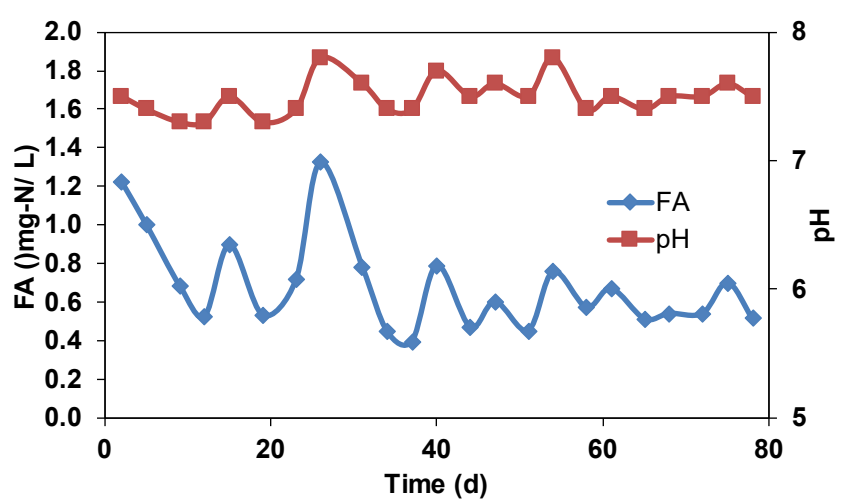

Figure 7. Free ammonia during reactor operation.

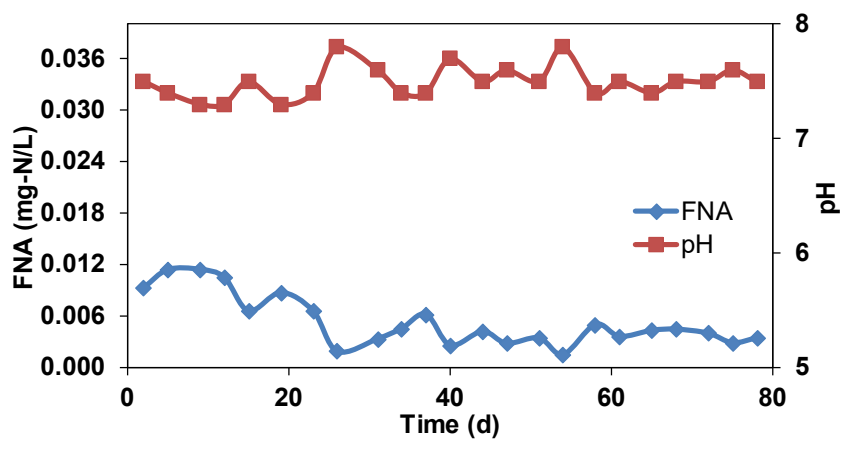

Figure 8. Free nitrous acid during reactor operation.

The concentration of FA and FNA is generally considered as essential parameter in stabilizing the reactor used in the anammox process. As indicated in the previous report, FA and FNA concentrations depend on substrate concentration, operating temperature, and $\mathrm{pH}$ in the reactor (Anthonisen et al. 1976). The Inhibition of anammox process was caused by FA is reversible. It has been reported that the recovery time was about one month, and FA did not substantially change the physical properties of the anammox. In a batch experiment, FA concentrations 38 $\mathrm{mg} / \mathrm{L}$ can inhibit $50 \%$ the anammox process and $80 \%$ inhibition at $100 \mathrm{mg} / \mathrm{L}$ (Fernández et al. 2012). While in the continuous operation, higher concentration both ammonia and nitrite in the influent up to 1.500 and 500 $\mathrm{mg} / \mathrm{L}$ did not inhibit anammox process. At FA concentration increased up to $150 \mathrm{mg} / \mathrm{L}$, inhibition anammox was not observed. When FA reached $190 \mathrm{mg} / \mathrm{L}$, anammox activity dropped to $10 \%$ (Aktan, Yapsakli, and Mertoglu 2012). FA concentration in the study was 0.783 , while the FNA concentration was 0.005 , below the threshold, Figure $7-8$. The anammox process in the biofilm reactor with palm fiber was free from inhibitory factors during the study.

\section{Anammox biofilm on the palm fiber}

The utilization of palm fiber as an anammox biofilm carrier increased the nitrogen removal performance of the reactor. The large surface of palm fiber increased contact between anammox bacteria and artificial waste, Figure 9. Installation of a carrier along the UASB reactor also optimized by the distribution of anammox bacteria compared to anammox granule, where the removal of nitrogen mainly occurred at the bottom of the reactor due to the tendency of the settlement of granule. However, the small diameter of the fiber caused the anammox biofilm biomass failed to form a "bio-cake" as a step in the process of granulation anammox biofilm which will later be settled with increasing thickness of the biofilm and then detached from the carrier, because the anammox bacteria are likely to form granules (Vlaeminck et al. 2009).

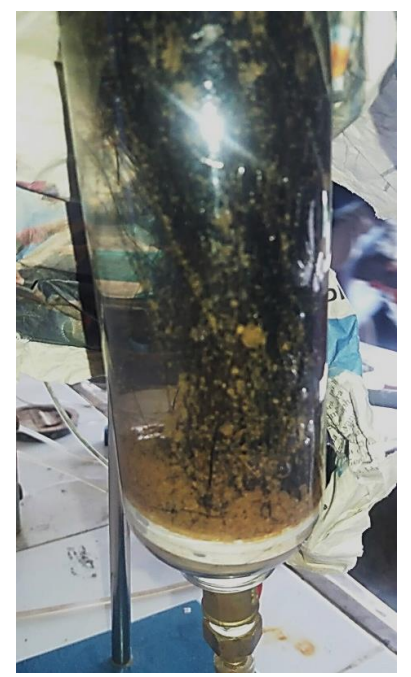

Figure 9. Anammox bacteria growth as biofilm in the palm fiber. 
The palm oil fiber, which is difficult to degrade, prevented inhibition of anammox process by degraded organic carbon. Chamchoi (2008) reported that concentrations of chemical oxygen demand (COD) over $300 \mathrm{mg} / \mathrm{L}$ decreased performance of the anammox process, while Yang et al. 2019 reported smaller levels of $200 \mathrm{mg} / \mathrm{L}$. The use of palm fiber can be an economical alternative natural carrier compared to commercial carriers such as non-woven carriers, membranes, filters, carbon fiber, and sponges. This material is commonly used as a filter for traditional water filtration. Therefore, the application of the anammox process using palm fiber for removal of nitrogen in Indonesia could be an applicable technology to prevent effect of nitrogen pollution.

\section{CONCLUSION}

Anammox process stable operated in the tropical temperature with a stoichiometric ratio close to anammox stoichiometry. Performance of nitrogen removal during the study on HRT $24 \mathrm{~h}$ and NLR $0.14 \mathrm{~kg}-\mathrm{N} / \mathrm{m}^{3}$.d obtained the optimum NRR $0.113 \mathrm{~kg}-\mathrm{N} / \mathrm{m}^{3}$.d, while on HRT 12 hours and NLR $0.29 \mathrm{~kg}-\mathrm{N} / \mathrm{m}^{3} . \mathrm{d}$ NRR increased to $0.196 \mathrm{~kg}$ $\mathrm{N} / \mathrm{m}^{3}$.d. The efficiency of ACE and NRE in HRT 24 hours reached $79 \%$ and $76 \%$, respectively and became $72 \%$ and 69\%, respective, in HRT $12 \mathrm{~h}$.

\section{ACKNOWLEDGEMENT}

This study was financially supported by the Ministry of Research, Technology and Higher Education of Indonesia (Grant No. 051/SP2H/LT/DRPM/2019).

\section{REFERENCES}

Aktan, Cigdem Kalkan, Kozet Yapsakli, and Bulent Mertoglu. 2012. "Inhibitory Effects of Free Ammonia on Anammox Bacteria." Biodegradation 23 (5): 751-62. https://doi.org/10.1007/s10532012-9550-0.

Ali, Muhammad, and Satoshi Okabe. 2015. "AnammoxBased Technologies for Nitrogen Removal:
Advances in Process Start-up and Remaining Issues." Chemosphere 141: 144-53. https://doi.org/10.1016/j.chemosphere.2015.06.0 94.

American Public Health Association, American Water Works Association, Water Environment Federation. 1999. "Standard Methods for the Examination of Water and Wastewater Standard Methods for the Examination of Water and Wastewater." Public Health, no. 1.

Anthonisen, AC, RC Loehr, TBS Prakasam, and EG Srinath. 1976. "Inhibition of Nitrification by Ammonia and Nitrous Acid." Water Pollution Control Federation 48 (5): 835-52. https://doi.org/10.1017/CBO9781107415324.00 4.

Chamchoi, N. 2008. "Inactivation of ANAMMOX Communities under Concurrent Operation of Anaerobic Ammonium Oxidation (ANAMMOX) and Denitrification." Bioresour. Technol. 99: 3331-36. http://ci.nii.ac.jp/naid/20001477773/en/.

Chen, Chong-jun, Xiao-xiao Huang, Chen-xiao Lei, Weijing Zhu, Ying-xu Chen, and Wei-xiang Wu. 2012. "Improving Anammox Start-up with Bamboo Charcoal." Chemosphere 89 (10): 1224-29. https://doi.org/10.1016/J.CHEMOSPHERE.201 2.07.045.

Chen, Wenjing, Xiaohu Dai, Dawen Cao, Xiaona Hu, Wenru Liu, and Dianhai Yang. 2017. "Characterization of a Microbial Community in an Anammox Process Using Stored Anammox Sludge." Water (Switzerland) 9 (11): 1-11. https://doi.org/10.3390/w9110829.

Fernández, I., J. Dosta, C. Fajardo, J. L. Campos, A. Mosquera-Corral, and R. Méndez. 2012. "Shortand Long-Term Effects of Ammonium and Nitrite on the Anammox Process." Journal of Environmental Management 95 (SUPPL.): S17074. https://doi.org/10.1016/j.jenvman.2010.10.044. 
Gerardi, Michael H. 2002. Nitrification and Denitrification in the Activated Sludge Process. New York: John Wiley and Sons, Inc.

Graaf, Astrid A Van De, Peter De Bruijn, Lesley A Robertson, Mike M Jetten, and J Gijs Kuenen. 1996. "Autotrophic Growth of Anaerobic Am Mon i u M-Oxi d Izi Ng m i Cro-Org a $\mathrm{n}$ Isms in a Fluidized Bed Reactor," no. 1996.

Hendrickx, Tim L.G., Yang Wang, Christel Kampman, Grietje Zeeman, Hardy Temmink, and Cees J.N. Buisman. 2012. "Autotrophic Nitrogen Removal from Low Strength Waste Water at Low Temperature." Water Research 46 (7): 2187-93. https://doi.org/10.1016/j.watres.2012.01.037.

Jin, Ren Cun, Guang Feng Yang, Jin Jin Yu, and Ping Zheng. 2012. "The Inhibition of the Anammox Process: A Review." Chemical Engineering Journal 197 (November 2017): 67-79. https://doi.org/10.1016/j.cej.2012.05.014.

Kindaichi, Tomonori, Ikuo Tsushima, Yuji Ogasawara, Masaki Shimokawa, Noriatsu Ozaki, Hisashi Satoh, and Satoshi Okabe. 2007. "In Situ Activity and Spatial Organization of Anaerobic Ammonium-Oxidizing (Anammox) Bacteria in Biofilms." Applied and Environmental Microbiology 73 (15): 4931-39. https://doi.org/10.1128/AEM.00156-07.

Loosdrecht, Mark C M van. 2008. "Innovative Nitrogen Removal.” Biological Wastewater TreatmentPrinciples, Modelling and Design., 139-54.

Ma, Bin, Yongzhen Peng, Shujun Zhang, Junmin Wang, Yiping Gan, Jiang Chang, Shuying Wang, Shanyun Wang, and Guibing Zhu. 2013. "Performance of Anammox UASB Reactor Treating Low Strength Wastewater under Moderate and Low Temperatures." Bioresource Technology 129: 60611.

https://doi.org/10.1016/j.biortech.2012.11.025.

Mulder, A, A A Van De Graaf, L A Robertson, and J G Kuenen. 1995. "Anaerobic Ammonium Oxidation Discovered in a Denitrifying Fluidized Bed
Reactor." FEMS Microbiol. Ecol. 16: 177-84.

Puyol, D., J. M. Carvajal-Arroyo, B. Garcia, R. SierraAlvarez, and J. A. Field. 2013. "Kinetic Characterization of Brocadia Spp.-Dominated Anammox Cultures." Bioresource Technology 139:94-100. https://doi.org/10.1016/j.biortech.2013.04.001.

Strous, M., J. J. Heijnen, J. G. Kuenen, and M. S M Jetten. 1998. "The Sequencing Batch Reactor as a Powerful Tool for the Study of Slowly Growing Anaerobic Ammonium-Oxidizing Microorganisms." Applied Microbiology and Biotechnology $50 \quad$ (5): 589-96. https://doi.org/10.1007/s002530051340.

Strous, M., J. J. Heijnen, J. G. Kuenen, M. S M Jetten, M. Strous, J. J. Heijnen, and J. G. Kuenen. 1998. “The Sequencing Batch Reactor as a Powerful Tool for the Study of Slowly Growing Anaerobic Ammonium-Oxidizing Microorganisms." Applied Microbiology and Biotechnology 50 (5): 589-96. https://doi.org/10.1007/s002530051340.

Strous, Marc, J. Gijs Kuenen, and Mike S.M. Jetten. 1999a. "Key Physiology of Anaerobic Ammonium Oxidation." Applied and Environmental $\begin{array}{llll}\text { Microbiology } & 65 & \text { (7): } & 3248-50 .\end{array}$ https://doi.org/papers2://publication/uuid/E9A15 73A-6D62-420E-94D0-CA7C84D0FEB9.

Strous, Marc, J Gijs Kuenen, and Mike S M Jetten. 1999b. "Key Physiology of Anaerobic Ammonium Oxidation Key Physiology of Anaerobic Ammonium Oxidation." Applied and Environmental Microbiology 65 (7): 0-3. https://doi.org/papers2://publication/uuid/E9A15 73A-6D62-420E-94D0-CA7C84D0FEB9.

Szatkowska, Av Beata, and Bjarne Paulsrud. 2014. "The Anammox Process for Nitrogen Removal from Wastewater - Achiewements and Future Challenges." Innsendte Artikler 2: 186-94.

Vlaeminck, Siegfried E., Akihiko Terada, Barth F. Smets, Davy Van Der Linden, Nico Boon, Willy Verstraete, and Marta Carballa. 2009. "Nitrogen 
Removal from Digested Black Water by One-Stage Partial Nitritation and Anammox." Environmental Science and Technology 43 (13): 5035-41. https://doi.org/10.1021/es803284y.

Widyawati, Nugraheni. 2011. Sukses Investasi Massa Depan Dengan Bertanam Pohon Aren. Yogyakarta: LILY PUBLISHER.

Yang, Jingyue, Jun Li, Zhaoming Zheng, and Liangang Hou. 2019. "Effect of Organic Matters on
Anammox Coupled Denitrification System: When Nitrite Was Sufficient.”

Zulkarnaini, Qin Yujie, Ryoko Yamamoto-ikemoto, and Norihisa Matsuura. 2018. "One-Stage Nitritation/Anammox Process Using a Biofilm Reactor with Two-Inflow." Journal of Water and Environment Technology 16 (2): 106-14. https://doi.org/10.2965/jwet.17-050. 